\title{
TARGET COSTING: ADOPTION AND ITS RELATIONSHIPS WITH COMPETITION INTENSITY, INTENDED STRATEGY AND FIRM SIZE
}

\author{
Helmi Hammami ${ }^{1}$, Mohammed Al-Omiri², \\ Taoufik Bouraoui ${ }^{3}$ and Ousama A. A. ${ }^{4}$ \\ ${ }^{1}$ Rennes School of Business, France. \\ E-mail: helmi.hammami@esc-rennes.com \\ ${ }^{2}$ Um Al Qura University, Saudi Arabia. \\ E-mail: mfomiri@uqu.edu.sa \\ ${ }^{3}$ Rennes School of Business, France. \\ E-mail: Taoufik.Bouraoui@esc-rennes.com \\ ${ }^{4}$ Qatar University, Qatar. \\ E-mail: osamaanam@gmail.com
}

\begin{abstract}
The paper aims to examine the level of the adoption of the target costing (TC) system by Saudi manufacturing companies and its relationships with competition intensity, intended strategy and firm size. The paper used a questionnaire survey to measure the adoption of TC and the effect of competition intensity and intended strategy on this adoption. Descriptive statistic and regression analysis were preformed to analyse the data and obtain the results. This study found that Saudi manufacturing companies were interested to adopt the TC system. In addition, it found that the competition intensity positively affects TC adoption. Moreover, the study found that companies that used a differentiation strategy were more inclined to adopt the TC than those that used a cost leadership strategy. Finally, it found that large manufacturing companies tend to adopt TC more than small ones. This is among the pioneer studies to study the TC system in Saudi Arabia, introducing a new area of investigation. Moreover, the study contributes to managerial accounting research in developing economies by providing new insights into the underexplored Saudi Arabia market. The findings of this paper could elucidate the importance of adoption of TC as a technique with a potential to support the economic growth of the country.
\end{abstract}

Keywords: target costing, competitive environment, cost leadership strategy, differentiation strategy, emerging markets, Saudi Arabia.

$\underline{\text { ARTICLE INFO }}$

Article History:

Received: 2 August 2019

Accepted: 13 November 2019

Published: 31 December 2019 


\section{INTRODUCTION}

In their seminal work "Relevance Lost", Johnson and Kaplan (1987) argued that management accounting systems (MASs) failed to capture the reality of the changing business environment that companies were evolving in and that the management accounting discipline was 'in crisis'. The output information presented to managers was often incorrect and inaccurate because MASs failed to cope with the requirements of the business environment. Accounting information partially lost its relevance and ability to reflect the complexity of the environment of companies. The need for improved costing systems that can optimally reflect the complete picture is pressing and therefore new management practices are expected to emerge (Atkinson et al., 1997; Baines \& Langfield-Smith, 2003; Alnoor et al., 2005). Considerable efforts have been made to introduce innovative management accounting practices, such as Target Costing (TC), that are in phase with the pace of change across different industries (Ax et al., 2008; Nimtrakoon \& Tayles, 2015).

Today, competition undoubtedly requires firms to implement all possible strategies to deliver products and services that meet customers' demands for quality, functionality, and price. Firms are often torn between charging low prices, as dictated by competition, and providing high-quality products, as required by customers. Because price is determined by market conditions, a new system of profit planning and cost management is needed. The focus of TC is on the customer, product design, and optimal use of resources along the entire supply chain; therefore, it is ideal to meet the need for change (Helms et al., 2005).

The TC technique works 'backward' from traditional cost-plus methods (Helms et al., 2005). It helps manage costs during the product design stage, specifically by setting a target cost and subtracting the desired profit margin from the market price (Ewert \& Ernst, 1999). When the product being developed does not meet the target cost and profit, it is unlikely to be introduced into the market (Helms et al., 2005). Several studies reported the managerial implications of TC adoption. TC is an efficient technique for cost reduction and profit optimisation (Tani et al., 1994; Monden \& Hamada, 1991; Ellram, 2000; Dekker \& Smidt, 2003). Moreover, the technique seriously considers customer satisfaction through market-oriented product 
development (Dekker \& Smidt, 2003; Tani et al., 1994), which strategically improves quality. While implementing a TC system, all supply chain partners must find means to reduce their costs (Helms et al., 2005). Therefore, TC can facilitate the understanding of the supplier's cost structures and improve cost monitoring, through an increase in cost accountability (Ellram, 2000).

The current paper reinforces the growing interest in the study of the diffusion of management accounting innovation (Gosselin, 1997, 2011; Askarany \& Smith, 2008; Baines \& Langfield-Smith, 2003), with a focus on developing markets. In fact, most of the studies on the implementation of TC, in particular, have been conducted in Western and developed countries, including Australia (Chenhall \& Langfield-Smith, 1998; Wijwardena \& De Zoyasa, 1999), New Zealand, the United Kingdom and the United States (Guilding et al., 2000), and Germany (Horvath \& Tani, 1997). Despite these numerous contributions few researchers have studied TC adoption in the context of emerging markets (Joshi, 2011; Sulaiman et al., 2004; Ilias et al., 2010; Anh et al., 2011; Joshi et al., 2011). None of the aforementioned studies have considered the Saudi Arabian market. To the best of our knowledge, this research is the first, so far, to specifically study TC in Saudi Arabia.

The paper aims to examine the extent of the adoption of TC systems among manufacturing companies in Saudi Arabia. In addition, it investigates the effect of the intensity of competition (i.e. competitive environment), product differentiation (PD) strategy and cost leadership (CL) strategy on the adoption of TC system. The findings of this study are undoubtedly of considerable concern to academicians and practitioners. From an academic perspective, the study enriches the scant pool of existing literature on managerial accounting practices and techniques currently used in Saudi Arabian businesses (Al-Namri, 1993; El-Baishi et al., 2003). Moreover, it represents the most recent survey that specifically focuses on a particular management accounting technique, namely TC. Most of the previous research simultaneously considered the extent of application of various management accounting practices (El-Baishi et al., 2003; Khalid, 2005; McLean \& Moustafa, 2011). The present study is the first of its type with explanations regarding adoption of TC in Saudi Arabia. 
TC is relatively a new managerial technique. It has been more widely applied in developed countries than in developing ones. The present study also fills the gap regarding the application of TC in developing markets and economies in transition (Terdpaopong \& Visedsun, 2014), such as the Saudi Arabian economy. By comparing the experiences of developing and developed countries, we may draw conclusions that help to better understand managerial accounting practices not only in the context under investigation but also in the developed countries themselves (Anh et al., 2011).

The present study is also of interest to managers, controllers, production managers, and regulators interested in the development of the Saudi Arabian manufacturing industry. The research results highlight practical issues regarding the effects of external variables, such as the extent of competition, and internal variables, such as the strategy and size of the firm, on TC adoption. The study will interest Saudi Arabian managers because many of them have received Western education and are inclined to adopt new managerial techniques that will enable their firms to progress (Taylor \& Albasri, 2014). From an alternative perspective, this study is of interest to government bodies such as the Chamber of Commerce and Industry that strives to make the Saudi Arabian industry more competitive and improve its presence on regional and international levels. These government bodies would agreeably view exposure to the best practices that would boost the performance of the Saudi Arabian manufacturing sector (Henry \& Springborg, 2001; Seznec \& Kirk, 2011).

On a larger scale, the present study could also be significant for neighbouring countries because of the numerous similarities they share with Saudi Arabia (particularly the GCC countries: Qatar, Oman, Bahrain, Kuwait, and the UAE). The Saudi Arabian experience with the adoption of TC could be an insightful one that may encourage several other countries to follow suit.

\section{BACKGROUND OF SAUDI ARABIA ECONOMY}

With a population of approximately 30 million (MEP, 2013), Saudi Arabia is the strongest and largest economy in the Middle East (Alsaeed, 2006). According to the Global Competitiveness Index (World Economic Forum, 
2014), Saudi Arabia was ranked the 24th most competitive economy among 144 countries. It was 2 nd to the United Arab Emirates (UAE) among the GCC countries in 2014. The economy of the country is vibrant and showed an annual growth rate of more than 5 per cent during the last five years, with a culmination of 10 per cent in 2011 (FocusEconomics, 2015). Although 81.9 per cent of the country exports are raw material (MEP, 2013), a top priority of the Saudi Arabian government, since the early 1990s, has been to eventually build an oil-independent economy. Public sector growth and the overdependence on fossil energy are giving room to private sector initiatives to build-up for a diversified manufacturing base (Azzam, 1993; MEP, 2013). The Saudi Arabian manufacturing industry today includes sectors such as food, textile, wood, and electrical supplies (MEP, 2013) apart from oil.

The major trends that shaped the Saudi Arabian economy are the growing range of locally produced goods and the modernisation of the manufacturing industry, especially due to the generous income from oil which was utilised optimally to ensure a stronger non-oil-reliant economy (Henry \& Springborg, 2001; Seznec \& Kirk, 2011) and joint ventures between local and international firms (Azzam, 1993). The private sector, with considerable support from the government, has been involved in the diversification strategy of the country, resulting in increased Foreign Direct Investments (FDI). The Saudi Arabian government undertook several measures to improve the investment climate in the country; hence, international corporations showed interest in the country and its promising future (IMF, 2014).

From this perspective, FDI not only brings capital but also employment, new technology, and new management methods and techniques (Alnamri, 1993; Hovidt, 2013). Furthermore, observers of the Saudi Arabian market agree that the government made considerable efforts for promoting education and training among the Saudi Arabian population (MEP, 2013). Many Saudis, who today occupy high positions, receive a large part of their education in the West, particularly in the United Kingdom and United States (Taylor \& Albasri, 2014). All these factors affected the transformation of managerial practices in the country, from basic leadership styles to the most complex techniques and standards used today in management. 


\section{LITERATURE REVIEW AND HYPOTHESES}

TC is clearly a manufacturing phenomenon (Dekker \& Smidt, 2003). It was first developed by Toyota to proactively manage multi-year profit plans that emerged from the organisation's strategy (Kato, 1993; Cooper \& Slagmulder, 1997, 1999; Ansari et al., 2007). Undoubtfully, TC is a cornerstone of the competitive success of Japanese companies. These new cost and management techniques intend to manage costs, quality, pricing, functionality, delivery times, and other parameters applied at the beginning of the product development process at levels that meet the standards, as perceived using customer needs (Clark \& Fujimoto, 1991).

TC has been adopted in several countries with a noticeable success (e.g. Chenhall \& Langfield-Smith, 1998; Guilding et al., 2000; Ansari et al., 2007; Anh et al., 2011). Its adoption is influenced by several factors, among which intensity of the competitive environment, strategy of the firm and size of the company are with significant effects (Hibbet et al., 2003; Dekker \& Smidt, 2003).

\section{Intensity of the Competitive Environment and TC}

Previous studies have suggested that when companies face the intensity of a competitive environment; they tend to employ relatively more sophisticated management accounting systems (Khandwalla, 1972; Simons, 1990; Libby \& Waterhouse, 1996). Indeed, this competition is the most important external factor encouraging managers to consider redesigning their costing system according to Burns and Kaplan (1987). The TC literature iterates the aforementioned discussion. Literature supports a positive relationship between the level of competition and the adoption of TC (Ellram, 2002; Dekker \& Smidt, 2003; Ansari et al., 2007; Ax et al., 2008). Hibbets et al. (2003) for example, using Porter's five-forces model, argue that intensive competitive pressures push firms to look for better opportunities to master their costs and streamline operations, which drives them to pay much attention to costs before they are committed (early in the product life cycle), Cooper and Slagmulder (1997) reached a similar conclusion arguing that as the intensity of competition increases, so does the value of TC. According to their concept of product survival zones, TC increases the probability that the new products launched will be inside their 
survival zones. Based on the preceding discussion, the following hypothesis is formulated:

$\mathbf{H}_{1}$ : The intensity of competition positively affects the adoption of the TC system.

\section{Intended Strategy and TC}

Previous research suggests that the type of strategy an organization selects establishes the need for innovation in the management accounting/ cost system in use (Langfield-Smith, 1997; Gosselin, 1997, 2011; Alcouf, 2002). The relationship between the strategy and the type of management accounting system in place is documented in the literature and strategy is identified as a defining factor of TC adoption (Simon, 1987, 1990; LangfieldSmith, 1997; Gosselin: 2011; Hibbets et al., 2003). Simons (1987) was among the pioneering studies that investigated the relationship between business strategy and the accounting control system in place. Interview data and questionnaire data of senior management within 76 firms provided evidence of the ways in which firms align their management control systems and strategy (Prospectors Versus Defenders). The management control system contributes to the difference between prospectors and defenders (cost control, forecast data, tight budget goals, etc.).

According to Hibbets et al. (2003), given the competitive environment of the firm, the decision to adopt TC depends on the firm strategy. They specifically investigated whether PD and CL strategies influence adoption of the TC. Data was gathered through interviews with managers of nine US and three German firms that have adopted TC. They concluded that there is difference between adopters of TC depending on the strategy they follow; differentiators are more inclined to adopt TC compared to cost leaders.

Specifically, building on Hibbets et al. (2003), we studied the impact of CL and PD on TC. In fact, firms can choose to compete with a low CL strategy or can pursue a PD strategy (Porter, 1985). CL implies that the firm aim to become the lowest-cost producer through economies of scale, low raw material prices, etc. neglecting meanwhile customer orientation (Frambach et. al, 2003). The competition is cost-oriented. For CL adopters, market advantage is achieved by the production and selling of products that 
are similar to the ones produced and sold by the competition but that incurs lower costs. Whereas, the goals of TC implementation are cost reduction, quality, profit, customer satisfaction, market-oriented product development, timely product introduction, time-to-market, understanding of the supplier's cost structures (Monden \& Hamada, 1991; Tani et al., 1994; Ellram, 2000). Based on these arguments the following sub-hypothesis was formulated:

$\mathbf{H}_{2 \mathbf{a}}$ : Cost leadership strategy negatively affects the adoption of the TC system.

Strategic initiatives undertaken by corporations to serve their customers may act as catalyst for adopting more sophisticated costing systems (Innes \& Mitchell, 1990; Gosslein, 1997). Companies with PD strategies have a greater impetus to provide products with attributes that are highly valued by customers such as design, brand, or distribution (Frambach et al., 2003). Hence, a firm needs to trace the flux, preferences attitude, and notably, consumer behaviour to arrive at an accurate formulation of affordable prices. The increasing global competition made the cost-based pricing an outdated managerial technique, whereas TC is emerging as a key strategic tool that agrees with the philosophy of PD strategy. Therefore, on the basis of the above, the following sub-hypothesis was proposed:

$\mathbf{H}_{\mathbf{2}}$ : Product differentiation strategy positively affects the adoption of the TC system.

\section{Size of the Firm and TC}

Previous empirical studies have noted that organisation size facilitates innovation. Large organisations have more complex and diverse facilities that aid the adoption of numerous innovations (Damanpour, 1992). For example, Abdel-Kader and Luther (2008) found a significant association between business size and sophisticated cost systems. Otley (1995) reported evidence of the effect of size on control techniques in studies of the role of MASs following a merger or takeover. In addition, Haldma and Laats (2002) argued that the sophistication level of cost accounting and budgeting systems increases with the size of a firm. However, few other studies reported conflicting or statistically non-significant results of the impact of business size on the adoption cost systems (Libby \& Waterhouse, 1996; Gosselin, 
1997, 2011; Cohen et al., 2005; Baird, 2007). Based on the previous arguments, the third hypothesis of this study is as follows:

$\mathbf{H}_{3}$ : Firm size positively affects the adoption of the TC system.

\section{RESEARCH METHOD}

\section{Research Sample and Data Collection}

In this study, researchers had to choose between conducting face-toface interviews with a small number of respondents and a large-scale survey with a large sample of manufacturing companies in Saudi Arabia. The largescale survey was privileged. To improve the validity and reliability of the measures used, the questionnaire was developed on the basis of previously conducted studies (Khandwalla, 1972; Govindarajan, 1988; Lee \& Miller, 1996; Innes et al., 2000; Al-Omiri \& Drury, 2007). Nevertheless, an initial draft was sent to two academicians teaching managerial accounting subjects in a reputable university in Saudi Arabia. Their comments improved the readability of the survey and its content.

For further validation of the survey, an updated pilot version was sent to four managerial accounting practitioners (two management accountants, one cost accountant, and one production manager) to seek feedback. Adopting the pilot version to the local context was extremely crucial for obtaining accurate results. The practitioners' feedback was extremely informative and improved the content of the survey. (Refer to the Appendix for the survey). Despite the predominance of English in Saudi Arabia as the language of business, the official language is Arabic and several high-level executives have an Arabic background. The practitioners and academicians both helped in assessing the adequacy of the bilingual (Arabic and English) versions of the survey.

The research sample consisted of 350 manufacturing companies randomly selected from the repository of the Ministry of Commerce and Industry. Hard copies of the surveys were sent by regular mail. Each package included a questionnaire with a personalised cover letter (all documents were written in both Arabic and in English) and a postage-paid, self-addressed 
envelope. The questionnaire was specifically addressed to the top leader of the company, and then it was forward to key individuals with knowledge of cost flow of the organisation. In the cover letter, few suggestions were provided such as CEO, Chief Accountant/CFO, Cost Manager, and Production Manager. Table 1 summarises the response rates by positions of the respondents. To increase the response rate, reminders were made through phone calls and emails. Obtaining appropriate feedback requires a continuous follow-up. The process of sending the surveys, performing follow-up, and collecting responses took approximately six months. A total of 150 surveys, representing a response rate of 42.85 per cent, were collected. However, after thoroughly scanning the returned questionnaires, 39 incomplete surveys were removed. Therefore, 111 completed and usable surveys were used in the analysis; hence, the net usable response rate was 31.71 per cent. For maintaining the quality for our results, we ran non-response bias tests. Comparisons between the sample frame and the responding firms using t-tests for 'size' were conducted. No significant difference was observed. Responses of respondents who replied without follow-up calls were not significantly different from the responses of those who answered after follow-up calls. In conclusion, non-response bias is unlikely to distort the results.

Table1: Survey Statistics

\begin{tabular}{lcccc}
\hline \multirow{2}{*}{ Respondent Position } & \multicolumn{2}{c}{ Returned Surveys } & \multicolumn{2}{c}{ Usable Surveys } \\
\cline { 2 - 5 } & $\mathbf{N}$ & Percentage & $\mathbf{N}$ & Percentage \\
\hline Chief Accountant/CFO & 76 & $50.67 \%$ & 59 & $53.15 \%$ \\
CEO & 37 & $24.67 \%$ & 31 & $27.93 \%$ \\
Cost Manager & 17 & $11.33 \%$ & 8 & $7.21 \%$ \\
Production Manager & 8 & $5.33 \%$ & 5 & $4.50 \%$ \\
Cost Engineer & 6 & $4 \%$ & 3 & $2.70 \%$ \\
Product Manager & 4 & $2.67 \%$ & 3 & $2.70 \%$ \\
Project Manager & 2 & $1.33 \%$ & 2 & $1.80 \%$ \\
Total & 150 & $100 \%$ & 111 & $100.00 \%$ \\
Surveys out $(\mathrm{n}=350)$ & 150 & $42.85 \%$ & 111 & $31.72 \%$ \\
\hline
\end{tabular}




\section{Research Variables}

This study investigated the relation between TC (dependent variable) and the intensity of competition, the firm strategy, and the firm size (independent variables). All variables, except for size, required the use of perceptive measures and thus required multi-question Likert-type scales. We measured the TC system variable over three dimensions using a multiquestion Likert-type seven-point scales to derive the composite score (Drury \& Tyles, 2000; Al-Omiri \& Drury, 2007). The intensity of the competitive environment was approached through three questions adopted from previous studies to ensure validity (Khandwalla, 1972; Swenson, 1995; Anderson \& Young, 1999). Firm strategy is a combination of two variables: CL strategy and PD strategy. On the basis of studies by Govindarajan (1988) and Lee and Miller (1996), we measured the CL strategy through two items and the PD strategy through five items. We used a Likert-type scale ranging from 1 to 7. Firm size was measured as the annual sales turnover in Saudi Riyals (SR) million. Natural logarithms were used to capture nonlinearity at large values.

Inter-scale reliability between items for each variable was determined by computing the Cronbach's alpha coefficient for internal consistency of the four constructs. The minimum reported alpha is 0.8 (CL strategy) which is significantly higher than the minimum acceptable level of 0.5 (Nunnelly, 1978). This confirms that our constructs are satisfactorily reliable. Details specifying the number of questions used and Cronbach's alpha are presented in Table 2.

Table 2: Reliability Test Results

\begin{tabular}{ccc}
\hline Variable & Number of Questions & Cronbach Alpha \\
\hline TC & 3 & 0.87 \\
COMPET & 3 & 0.91 \\
CLS & 2 & 0.80 \\
PDS & 5 & 0.92 \\
SIZE & 1 & Objective measure \\
\hline
\end{tabular}




\section{Regression Model}

To test the hypotheses specified earlier, the following regression model was applied:

$T C=\alpha+\beta_{1} C O M P E T+\beta_{2} C L S+\beta_{3} P D S+\beta_{4} S I Z E+\varepsilon$

Where:

$\mathrm{TC}=$ Level of TC adoption.

COMPET $=$ Intensity of the competition.

CLS $=$ Cost leadership strategy.

$\mathrm{PDS}=$ Product differentiation strategy.

SIZE $=$ Frim size .

\section{FINDINGS AND DISCUSSION}

The descriptive statistics results reported below in Table 3 confirm that TC is a system of interest among Saudi Arabian manufacturing companies (mean of 5.83). To assess whether the intensity of the competition, CL strategy, PD strategy and SIZE cause a difference between adopters and non-adopters of TC systems, both types of companies were compared. Firms were divided into two groups on the basis of the reported score on TC adoption. Firms that reported a score of 2 and below were classified as low TC adopters, whereas those that reported a score 5 and above were considered high TC adopters. The low and high TC adopter groups consisted of 46 and 36 firms, respectively. For comparison, we used the non-parametric Mann-Whitney U-test with the competitive environment intensity variable, PD strategy, and CL strategy. The t-Test was used for the variable 'size'. All p-values were significant at the 0.05 level.

Table 3: Descriptive Statistics Results

\begin{tabular}{lcccc} 
& Min. & Max. & Mean & Std. dev. \\
\hline TC & 1.031 & 6.678 & 5.839 & 0.63389 \\
COMPET & 2.556 & 6.431 & 5.5315 & 0.89823 \\
CLS & 1.334 & 5.2261 & 3.5874 & 0.32617 \\
PDS & 1.1246 & 6.1821 & 4.4820 & 0.71962 \\
SIZE & 23.39 & 438.27 & 274.73 & 382.785 \\
\hline
\end{tabular}


Table 4 summarises the statistics for each variable. Findings show that low and high TC adopters are significantly different with regard to the independent variables (competitive environment, PD strategy, CL strategy, and size).

Table 4: Independent Variables Effect on the Adoption of TC: High Vs Low Adopters

\begin{tabular}{lcc}
\multicolumn{1}{c}{ Variable } & N & Median \\
\hline COMPET & & \\
High Adopters & 46 & 5 \\
Low Adopters & 36 & 5 \\
Mann-Whitney Test: $\mathrm{p}=0.021$ & & \\
CLS & & \\
High Adopters & 46 & 4 \\
Low Adopters & 36 & 5 \\
Mann-Whitney Test: $\mathrm{p}=0.000$ & & \\
PDS & & \\
High Adopters & 46 & 6 \\
Low Adopters & 36 & 5 \\
Mann-Whitney Test: $\mathrm{p}=0.001$ & & \\
SIZE & & \\
High Adopters & 46 & \\
Low Adopters & 36 & \\
T-test: $p=0.031$ & & \\
\hline
\end{tabular}

Table 5 presents the results of the regression results. The last two columns of the table report the collinearity statistics. The Variance Inflation Factors (VIF) were significantly lower than 10 (critical threshold showing high levels of multi-collinearity) and the tolerance values were above 0.2. A positive sign for the logistic regression indicates that the variable is positively related to $\mathrm{TC}$ adoption, whereas a negative sign indicates that as the variable increases, the company is less keen to adopt TC. Results show that all the significant variables are as predicted. The overall model was also significant at the 0.05 level $(\mathrm{F}$ ratio $=3.168 \mathrm{p}$-value $=.000)$ with an adjusted $\mathrm{R}^{2}$ of 0.207 . 
Table 5: Regression Results

\begin{tabular}{|c|c|c|c|c|c|c|c|}
\hline & $\begin{array}{l}\text { Expected } \\
\text { Sign }\end{array}$ & $\begin{array}{l}\text { Std. } \\
\text { Error }\end{array}$ & $\begin{array}{c}\text { Std. } \\
\text { Coefficients } \\
\text { Beta }\end{array}$ & $\mathbf{T}$ & Sig. & \multicolumn{2}{|c|}{$\begin{array}{l}\text { Collinearity } \\
\text { Statistics }\end{array}$} \\
\hline Constant & & 22.532 & & .054 & .459 & Tolerance & VIF \\
\hline COMPET & + & 2.414 & .023 & .255 & .022 & .622 & 1.503 \\
\hline CLS & - & 3.430 & -.023 & -.358 & .023 & .644 & 1.411 \\
\hline PDS & + & 2.673 & .069 & .650 & .031 & .608 & 1.662 \\
\hline SIZE & + & 2.104 & .074 & .881 & .044 & .848 & 1.322 \\
\hline $\mathrm{R}^{2}$ & & .455 & & & & & \\
\hline Adjusted $\mathrm{R}^{2}$ & & .207 & & & & & \\
\hline $\mathrm{F}$ & & 3.168 & & & & & \\
\hline Significance $(p)$ & & 0.000 & & & & & \\
\hline
\end{tabular}

The results showed that $\mathrm{H}_{1}$ (i.e. intensity of competition is positively affect the adoption TC system) was accepted. An increase in the intensity of the competitive environment significantly $(p=0.022)$ affects the adoption of TC in the predicted (positive) direction (.660). The findings of this research are in line with previous studies that also found a positive relationship between the intensity of competition and the adoption of TC (Ansari \& Bell, 1997; Cooper \& Slagmulder, 1997, Ellram, 2002; Hibbets et al., 2003; Ax et al., 2008).

All indicators show that the Saudi Arabian market is becoming increasingly competitive. The high rank of the Saudi Arabian market in the Global Competitiveness Index 2014-2015 indicates the dynamics prevailing in the country for some years (rank 24). In addition, the government has made efforts to support private initiatives as leverage for economic diversification (Henry \& Springborg, 2001; Al-Baishi et al., 2003; Seznec \& Kirk, 2011; Aljebrin, 2012; IMF, 2014). The private sector is intended to be the primary medium for economic diversification of the Saudi Arabian economy in the coming decades (Al-Baishi et al., 2003). Because of the increased competition, local companies are discovering ways to gain a share of the market. In fact, several studies have shown that local Saudi Arabian companies are striving to adopt new managerial techniques and methods to enable them to survive competition (Azzam, 1993; Al-Nemri; 1993; Al-Awadh, 1996; Magd, 2006). The eforts of the government to 
facilitate investment by foreign companies to invest in the country has created additional dynamics that culminated in several joint projects. Often driven by profit maximisation, foreign investors, especially multinational corporations, transfer their know-how to local companies. The transfer of technology (including accounting techniques) ensures efficient management and profit maximisation. The presence of international factors in the local market fosters competition resulting in innovation.

With regard to strategy the impact is very clear. The results showed that $\mathrm{H} 2 \mathrm{a}$ (i.e. the $\mathrm{CL}$ strategy has a negative effect on the adoption of the TC system) was accepted. In fact, the adoption of the TC system decreases in response to an increase in CL strategy $(-1.338, \mathrm{p}=.023)$. This result is as expected because the entire philosophy of TC opposes the CL strategy, which is characterised by the rigorous use of budget and strict management of production for lowering cost (Helms et al., 2003; Ansari et al., 2007). For the case of Saudi Arabia, these findings reflect the general trend of quality pursuing philosophy several Saudi companies are following, either by choice or by obligation. In fact, the emphasis of delivering good quality services and goods and putting customers' satisfaction in the front line is widespread in several Saudi companies (Magd, 2006).

The $\mathrm{H} 2 \mathrm{~b}$ (i.e. the PD strategy has a positive effect on the adoption of the TC system) was also accepted. This outcome agrees with previous studies on the effect of strategy on the adoption of costing systems (Langfield-Smith, 1997; Gosselin, 1997; 2011; Hibbets et al., 2003). Efforts of the Saudi government to upgrade the quality of the services and the products, and the competitiveness of local companies pushed the latter to sharpen their managerial techniques and tools to position themselves in an increasingly competing market (Azzam, 1993, Al-Nemri, 1993; Magd, 2006; IMF, 2014). Therefore, the adoption of strategies like PD has an effect on performance through achieving a competitive advantage (Al-Awadh, 1996). In this regard, TC reinforces the will for innovation and survival exhibited by several Saudi Arabian companies.

As expected, firm size had a positive effect on the adoption of the TC system. Thus, the $\mathrm{H} 3$ was also accepted. The larger the company, the higher is the probability of the adoption of a more sophisticated costing system. The results of the present study are similar to those of previous studies 
regarding the effect of size on the adoption of more sophisticated costing systems (Al-Omiri \& Drury, 2007; Abdel-Kader \& Luther, 2008). Larger Saudi Arabian companies have easier access to funding and other resources. The availability of resources helps them to innovate and actively adopt new managerial techniques to improve their market positions.

\section{CONCLUSION}

The present study aimed to give a first account of the adoption of the TC technique in the Saudi Arabian context. Even though this managerial technique has been widely used in developed nations and other emerging countries, there was no formal attempt to look at it in Saudi Arabia. The findings of the research come to fill the scarcity of knowledge about the Saudi market.

From the outcome of our investigation, we conclude that when competition is high, companies tend to adopt innovative costing techniques such as TC. Also, depending on the strategy adopted by the firm (CL or $\mathrm{PD}$ ), a negative and positive relationship of TC adoption with the first and second strategy, respectively were reported. This is understandable considering the paradigm around which TC is built (Hibbets et al., 2003; Anti \& Novićević, 2011). Moreover, the output agrees with the results of previous literature in developed and developing countries (Tani et al., 1994; Dekker \& Smidt, 2003; Ansari et al., 2007; Terdpopong \& Visedsun, 2014; Nimtrakoon \& Tayles, 2015).

In Saudi Arabia, the manufacturing industry has been evolving since the 1970s, with a significant impetus in the 1990s, as a result of government measures to raise the standard of the manufacturing industry and expand it further by attracting foreign investments (Alnamri, 1993; Hovidt, 2013). Therefore, the modernization of the manufacturing sector, the adoption of new management techniques and conquest of markets Saudi Arabian firms with no choice to survive competition (Al-Namri, 1993; Al-Awadh, 1996; Khalid, 2005).

Saudi Arabian firms aim to expand to new markets and therefore are willing, whenever possible, to adopt innovative management techniques 
that would enable them to achieve this objective. Consequently, cost is not anymore the only driver for Saudi Arabian firms, especially for a market with more demanding customers, knowing that the Saudi Arabian market is the largest market for foreign goods and services in the Middle East (NCB Economist, 1995). Other factors such as customer satisfaction and quality are considered. Companies seeking success have to adapt to market requirements. Therefore, a good costing system (such as TC) can enable tracking of these new variables.

Coping with change and implementing costing systems such as TC is an enormous investment that requires the mobilisation of a considerable amount of resources. Small companies usually encounter more difficulties than large ones in obtaining funding. The present study confirms this trend. Large Saudi Arabian companies are more capable of adopting TC than small ones are.

The present study counters the dominant impression that Saudi Arabia is backward in terms of managerial techniques and practices adopted by local firms (Al-Ansari, 1993, Khalid, 2005) as it highlights the spread of innovative managerial accounting techniques such as TC in the Saudi context. Furthermore, the present study is timely and might interest regulators and decision-makers who aim to transform the Saudi Arabian economy by 2030. A few years ago, Japan successfully became a world leader in the automobile industry partly by adopting innovative management tools such as TC. Saudi Arabian corporate decision-makers and regulators, inspired by the results of the present study, may consider adoption of TC as an endeavour to improve the positioning of the manufacturing industry in the country, which in turn will support the so sought after strategy of creating a strong oil-free economy by 2030 .

This research opens several ways for future studies. First, in the current paper the various industries that constitute the entire manufacturing industry were not distinguished in detail. Investigating the composition of the manufacturing industry may yield more interesting results. Second, the study did not focus on the characteristics of the Saudi Arabian economy and the potential effect on the adoption of new management accounting techniques like TC. Industry and country characteristics are potential constructs that affect the adoption of new managerial and costing techniques (Chang et al., 
2003). Future studies could replicate the present one by considering these two dimensions. Third, this study only examined the effects of two factors along with size, namely competition and strategy. Future research could focus on other factors, such as customer profiles and performance indicators.

A crucial variable that could also explain the fervour for TC could be the quality of the new generation of leaders of Saudi Arabian companies. Saudi Arabia sends a high number of students abroad to receive higher education, primarily to the United States and United Kingdom (Taylor $\&$ Albasri, 2014). As a result, these students return to Saudi Arabia with the new managerial techniques and practices that they have learnt abroad. Investigating the relationship between the return of Saudi Arabian students and the change of MASs would provide a perspective to better understand the Saudi Arabian scenario of management accounting for further research.

The research method also has some shortcomings. The survey method is widely adopted for managerial accounting research; however, it has its own limitations. Self-reporting may not be completely accurate. Future research may be performed with improved data collection, for instance, increasing the number of face-to-face interviews or using secondary data. Considering case studies could also a viable alternative. Despite the aforementioned limitations, the findings of our research provide additional information regarding the adoption of cost management systems in developing countries, particularly Saudi Arabia. Considerable work was performed to obtain information regarding this underexplored economy. The results of the present study will motivate future researchers to focus on fast-developing, underexplored markets.

\section{REFERENCES}

Abdel-Kader, M., \& Luther, R. (2008). The impact of firm characteristics on management accounting practices: A UK-based empirical analysis. British Accounting Review, 40(1), 2-27.

Alnamri. M. J. (1993). Management accounting practices: In Saudi Arabia: a comparative analysis of Saudi and Western approaches. Unpublished $\mathrm{PhD}$ thesis, Newcastle University, Newcastle. 
Alnoor, B., Gosselin, M., \& Ncube, M. (2005). Strategy and activity based costing: A cross national study of process and outcome contingencies. International Journal of Accounting, Auditing and Performance Evaluation, 2(3), 187 - 205.

Al-Omiri, M., \& Drury, C. (2007). A survey of factors influencing the choice of product costing systems in UK organizations. Management Accounting Research, 184), 399-424.

Alsaeed, K. (2006). The association between firm-specific characteristics and disclosure: The case of Saudi Arabia. Managerial Auditing Journal, 21(5), 476-496.

Anderson, S. W., \& Young, S. M. (1995). The impact of contextual and process factors on the evaluation of activity-based costing systems. Accounting Organizations and Society, 24(7), 525-559.

Anh, D., Nguyen, D., \& Mia, L. (2011). Western management accounting practices in Vietnamese enterprises: Adoption and perceived benefits. Pacific Accounting Review, 23(2), 42-164.

Ansari, S. L., Bell, J. E., \& the CAM-I Target Cost Core Group (1997). Target costing: The next frontier in strategic cost management. New York: McGraw-Hill.

Ansari, S. L., Bell, J. F., \& Okano, H. (2007). A review of literature of target costing and cost management. In C. S., Chapman, A. G., Hopwood, M. D. Shields, (Ed.), Handbook of MA Research, 2, (pp. 507-530). Oxford: Elsevier.

Anti, L., \& Novićević, B. (2011). Target costing for the purpose of generic strategies realization. Economics and Organization, 8, 247-261.

Askarany, D., \& Smith, M. (2008). Diffusion of innovation and business size: A longitudinal study of PACIA. Managerial Auditing Journal, 23(9), 900-916. 
Ax, C., Greve, J., Nilsson, U. (2008). The impact of competition and uncertainty on the adoption of target costing. International Journal Production Economics, 115(1), 92-103.

Azzam, H. (1993). Saudi Arabia-Joint ventures in the Kingdom. Middle East Executive Reports, 16(4), 9-12.

Baines, A., \& Langfield-Smith, K. (2003). Antecedents to management accounting change: A structural equation approach. Accounting, Organisations and Society, 28(7-8), 675-698.

Baird, K. M., Harrison, G. L., \& Reeve, R. C. (2004). Adoption of activity management practices: A note on the extent of adoption and the influence of organizational and cultural factors. Management Accounting Research, 15(4), 383-399.

Bruns, W. J. Jr., \& Kaplan, R. S. (1987). Accounting and management: Field study perspectives. Cambridge, MA: Harvard Business School Press.

Chenhall, R. H., \& Langfield-Smith, K. (1998). Adoption and benefits of management accounting practices an Australian study. Management Accounting Research, 9(1), 1-19.

Clark, K., \& Fujimoto, T. (1991). Product development performance -Strategy, organization, and management in the world auto industry. Boston, MA: Harvard Business School Press.

Cooper, R. (1988). The rise of activity-based costing-part three: How many cost drivers do you need, and how do you select them? Journal of Cost Management for the Manufacturing Industry, Winter, 34-46.

Cooper, R., \& Slagmulder, R. (1997). Target costing and value engineering. Portland: Productivity Press.

Cooper, R., \& Slagmulder, R. (1999). Develop profitable new products with target costing. Sloan Management Review, 40(4), 23-33. 
Cooper, R., \& Yoshikawa, T. (1994). Inter-organizational cost management systems: The case of the Tokyo-Yokohama Kamakura supplier chain. International Journal of Production Economics, 34(1), 51-62.

Damanpour, F. (1992). Organizational size and innovation. Organization Studies, 13(3), 375-402.

Davila, T. (2000). An empirical analysis on the drivers of management control systems design in new product development. Accounting, Organizations and Society, 25(4-5), 383-409.

Davila, T., \& Wouters, M. (2004). Designing cost-competitive technology products through cost management. Accounting Horizons, 18(1), 13-26.

Dean, J. W., \& Evans, J. R. (1994). Total quality: Management organization and strategy. St. Paul, MN: West Publishing Co.

Dekker, H., \& Smidt, P. (2003). A survey on the adoption of use of target costing in Dutch firms. International Journal of Production Economics, 84(3), 293-305.

Drury, C., \& Tayles, M. (2000). Cost system design and profitability analysis in UK companies. London: Chartered Institute of Management Accountants.

El-Ebaishi, M., Karbhari, Y., \& Naser, K. (2003). Empirical evidence on the use of management accounting techniques in a sample of Saudi manufacturing companies. International Journal of Commerce \& Management, 13(2), 74-101.

Ellram, L. M. (2000). Purchasing and supply management's participation in the target costing process. Journal of Supply Chain Management, $36(2), 39-52$.

Ewert, R., \& Ernst, C. (1999). Target costing, coordination and strategic cost management. European Accounting Review, 8(1), 23-49. 
Frambach, R. T., Prabhu, J., \& Verhallen, T. M. (2003). The influence of business strategy on new product activity: The role of market orientation. International Journal of Research in Marketing, 20(4), 377-397.

Gosselin, M. (1997). The effect of strategy and organizational structure on the adoption and implementation of activity-based costing. Accounting, Organizations and Society, 22(2), 105-122.

Gosselin, M. (2011). Contextual factors affecting the deployment of innovative performance measurement systems. Journal of Applied Accounting Research, 12(3), 260 - 277.

Govindarajan, V. (1988). Decentralization, strategy, and effectiveness of strategic business units in multibusiness organizations. Academy of Management Review, 11(4), 840-856

Guilding, C., Cravens, S., \& Tayles, M. (2000). An international comparison of strategic management accounting practices. Management Accounting Research, 11(1), 113-135.

Haldma, T., \& Laats, K. (2002). Contingencies influencing the management accounting practices of Estonian manufacturing companies. Management Accounting Research, 13(4), 379-400.

Helms, M. M., Ettkin, L. P., Baxter, J. T., \& Gordon, M. W. (2005). Managerial implications of target costing. Competitiveness Review, 15(1), 49-57.

Henry, C. M., \& Springborg, R. (2001). Globalization and the politics of development in the Middle-East. Cambridge: Cambridge University Press.

Hibbets, A. R., Albright, T., \& Funk, W. (2003). The competitive environment and strategy of target costing implementers: Evidence from the field. Journal of Management, 15(1), 65-81.

Horvath, P., \& Tani, T. (1997). Japanese-German comparison of target costing management. Paper presented at the EAA Congress in Graz. 
Hvidt, M. (2013). Economic diversification in the GCC countries-past record and future trends. (Research Paper No. 27). Kuwait Programme on Development, Governance and Globalisation in the Gulf States.

Ilias, A. Abd Razak, M., \& Yasoa, M. (2010). The preliminary study of management accounting practices (MAPs) in small business. Global Business and Management Research: An International Journal, 2(1), 79-88.

Innes, J., \& Mitchell, F. (1990). The process of change in management accounting: Some field study evidence. Management Accounting Research, 1(1), 3-19.

Innes, J., Mitchell, F., \& Sinclear, D. (2000). Activity-based costing in the UK's largest companies: A comparison of 1994 and 1999 survey results. Management Accounting Research, 11(3), 349-362.

International Monetary Fund (IMF). (2015). Saudi Arabia: Tackling Emerging Economic Challenges to Sustain Growth (pp. 1-81). Washington DC, USA, International Monetary Fund.

Johnson, T., \& Kaplan, R. S. (1987). Relevance lost: The rise and fall of management accounting. Boston, Massachusetts: Harvard Business School Press.

Joshi, P. L., Bremser, W. G., Deshmukh, A., \& Kumar, R. (2011). Diffusion of management accounting practices in gulf cooperation council countries. Accounting Perspectives, 10(1), 23-53.

Khalid, A. (2005). Activity-based costing in Saudi Arabia's largest 100 firms in 2003. Journal of American Academy of Business, 6(2), 285-292.

Khandwalla, P. (1972). The effects of different types of competition on the use of management control. Journal of Accounting Research, 10, $275-285$.

Langfield-Smith, K. (1997). Management control systems and strategy: A critical review. Accounting, Organizations and Society, 22(2), 207-232. 
Lee, J., \& Miller, D. (1996). Strategy, environment and performance in two technological contexts: Contingency theory in Korea. Organization Studies, 17(5), 729-750.

Libby, T., \& Waterhouse, J. H. (1996). Predicting change in management accounting systems. Journal of Management Accounting Research, 8, $137-150$.

Ministry of Economy and Planning (MEP) (2013). The Saudi Economy in figures (2013) (pp.1-11). Riyadh, Saudi Arabia: Ministry of Economy and Planning.

Monden, Y., \& Hamada, K. (1991). Target costing and kaizen costing in Japanese automobile companies. Journal of Management Accounting Research, 3(1), 16-34.

NCB Economist. (1995). Saudi Arabia external sectors and the impact of GATT. Saudi Arabia: National Commercial Bank.

Nimtrakook, S., \& Tayles, M. (2015). Explaining management accounting practices and strategy in Thailand. Journal of Accounting in Emerging Economies, 5(3), 269-298.

Porter, M. E. (1985). Competitive advantage. New York: Free Press. PorterCompetitive Advantage1985.

Saudi Arabia Economic Outlook. (2015). Focus Economics. Retrieved from http://www.focus-economics.com/

Seznec, J. F., \& Kirck, M. (2011). Industrialization in the Gulf: A socioeconomic revolution. London: Center for Contemporary Arab Studies, Georgetown University/Routledge.

Simons, R. (1990). The role of management control systems in creating competitive advantage: New perspectives. Accounting, Organizations and Society, 15(1-2), 27-143. 
Sulaiman, M., Nik Ahmad, N. N., \& Alwi, N. (2004). Management accounting practices in selected Asian countries. Managerial Auditing Journal, 19(4), 493-508.

Tani, T., Okano, H., Shimizu, N., Iwabuchi, Y., Fukuda, J., \& Cooray, S. (1994). Target cost management in Japanese companies: Current state of the art. Management Accounting Research, 4(5), 67-81.

Taylor, C., \& Albasri, W. (2014). The impact of King's Abdullah scholarship program in the US. Open Journal of Social Sciences, 2, 109-118.

Terdpaopong, K., \& Vusedsun, N. (2014). Target costing in manufacturing firms in Thailand. Journal of Social Sciences and Humanities, 1 (2), 29-39. 


\section{APPENDIX: ABBREVIATED RESEARCH SURVEY}

\section{PART 2: Target Costing:}

When answering, please consider the below definition of Target Costing:

"Target costing is an approach used during new product development/ design or when major changes are being made to existing products. It is an approach to determine a product's life-cycle cost which should be sufficient to develop specific functionality and quality, while ensuring its desired profit. It involves setting a target cost by subtracting a desired profit margin from a competitive market price.

Target costing essential elements include product pricing, profit planning and cost control management." (Ax et al., 2008)

\section{Section 1: Adoption of Target Costing}

1. Please indicate the extent to which Target Costing is used in your business?

Not at all

1

2

3

4

5

6

All products

2. If you are using another approach for costing, please indicate the extent to which you consider they are similar to Target costing.

$\begin{array}{ccccccc}\begin{array}{c}\text { Not at all } \\ \text { similar }\end{array} & 2 & 3 & 4 & 5 & 6 & \begin{array}{c}\text { Highly } \\ \text { similar }\end{array} \\ 1 & 2 & 3 & 4 & 7\end{array}$


3. Please indicate the extent to which you perceive the benefits of adopting Target Costing.

Not at all

Very

beneficial

1

2

3

4

5

6

7

\section{Section 2: Intensity of Competitive Environment}

1. How would you classify the market activities of your competitors?

Predictable

1

2

3

4

5

6

Less

Predictable

2. How would you qualify the future demand for the products that your company produces?

Certain

1

2

3

4

5

6

Uncertain

3. Current competition could cause the company to lose important shares of the market

Strongly

Disagree

1

2

3

4

5

6

Strongly

Agree

7

\section{Section 3: Strategy}

How would you best describe your company's strategy?

\section{A. Cost leadership}

1. Your company is competing by selling products at lower prices.

$$
\text { Very Low }
$$

1

2

2

3

3

4

5

Very High

6

7 
2. Your company is competing by selling products at higher prices.

$\begin{array}{ccccccc}\text { Very Low } & & & & & \text { Very High } \\ 1 & 2 & 3 & 4 & 5 & 6 & 7\end{array}$

\section{B. Differentiation strategy}

1. The position of your firm with regard to brand image is:
Very Low
1
2
3
4
5
Very High
$6 \quad 7$

2. The position of your firm with regard to advertising investments is:

Very Low

1

2

3

4

5

6

Very High

7

3. The position of your firm with regard to marketing and distribution channels is:
Very Low
$4 \quad 5$
Very High
1
2
3
56
7

4. The position of your firm with regard to innovation is:

Very Low

1

2

3

4

5

6

Very High

7

5. The position of your firm with regard to the number of new products is:

Very Low

1
2

3

4

5

6

Very High

7 